\title{
CORE SOFTENING IN CAVERNOUSLY WEATHERED TONALITE
}

\author{
JAMES L. CONCA AND GEORGE R. ROSSMAN \\ Division of Geological and Planetary Sciences, California Institute of Technology.? \\ Pasadena, California 91125
}

\begin{abstract}
Tonalite exhibiting cavernous weathering at Catavina, Baja California, was investigated to determine the factors which contribute to differential hardness within the rock. Soft cores have a high degree of chemical weathering as indicated by kaolinite content. Hematite formed from the leaching of biotite occurs in coatings on rock surfaces, but the hardening effect of the coating is insignificant compared to the coresoftening of the interior. The hardness, measured by an abrasion resistance hardness tester, is inversely correlated with kaolinite content in the tonalite. A one-dimensional water flow model was developed for core-softened, cavernously weathered boulders. It indicates that during infiltration and dessication the moisture flux is greatest through the cavern interior wall because of changes in the hydraulic conductivities induced by core softening. Therefore, the cavern interior wall should have the greatest weathering rate in the boulder.
\end{abstract}

\section{INTRODUCTION}

Core softening and case hardening of rock outcrops and residual surface boulders are widespread processes that act throughout different regions of the world and are especially abundant in arid to semi-arid areas (Conca and Rossman 1982). Core softening and case hardening are geologic processes in which the rock exterior becomes hard relative to the interior, resulting in a reduced rate of exterior weathering. The difference between these two processes concerns the evolution of the absolute hardness during weathering. With case hardening, the absolute hardness of the exterior increases with time, while the absolute hardness of the interior usually remains the same or decreases. However, during core softening, the absolute hardness of the exterior actually decreases with time but to a lesser degree than the interior, resulting in a differential hardness similar to that developed during case hardening. It has been found by the authors that many ostensibly case-hardened rocks are in fact coresoftened. Removal of local areas of the exterior (or weathering of exterior areas where either core softening or case hardening has

\footnotetext{
${ }^{1}$ Manuscript received April 30, 1984; revised August 6, 1984.

2 Contribution number 4058.
}

[JouRnal of GEOLOGY, 1985, vol. 93, p. 59-73] (C) 1985 by The University of Chicago. All rights reserved.

$0022-1376 / 85 / 9301-002 \$ 1.00$ not developed locally) can result in more rapid erosion of the more friable interior leading to the development of cave and pillar structures. In much of the tonalite from Catavina, Baja California, core softening and cavernous weathering are extensively developed (fig. 1).

A number of studies have been conducted concerning the differential weathering effects of cavernous weathering, tafoni, honeycomb, or alveolar weathering (Mustoe 1982; Jennings 1968). Processes cited for the origin of cavernous weathering include case-hardening (Dragovich 1969), core-softening (this study), salt weathering (Evans 1970; Goudie 1974; Selby 1971), hydration shattering (White 1976), insolation (Rice 1976), frost action (Fahey 1973), and wind erosion (Whalley and McGreevy 1983 give a rather complete review of the recent weathering literature). Many of these weathering processes are not mutually exclusive, and while a single process may dominate in many situations, it is by no means the rule. Several mechanisms of primary rock breakdown and constituent redistribution can occur simultaneously or sequentially both in space and time, especially in arid environments where the decreased water contents slow rates considerably, allowing expression of a greater variety of mechanisms. Striking examples of such relationships have been observed by the authors in the Dry Valleys of the Antarctic (Conca 1984) where core softening and case hardening have decreased the permeability of 


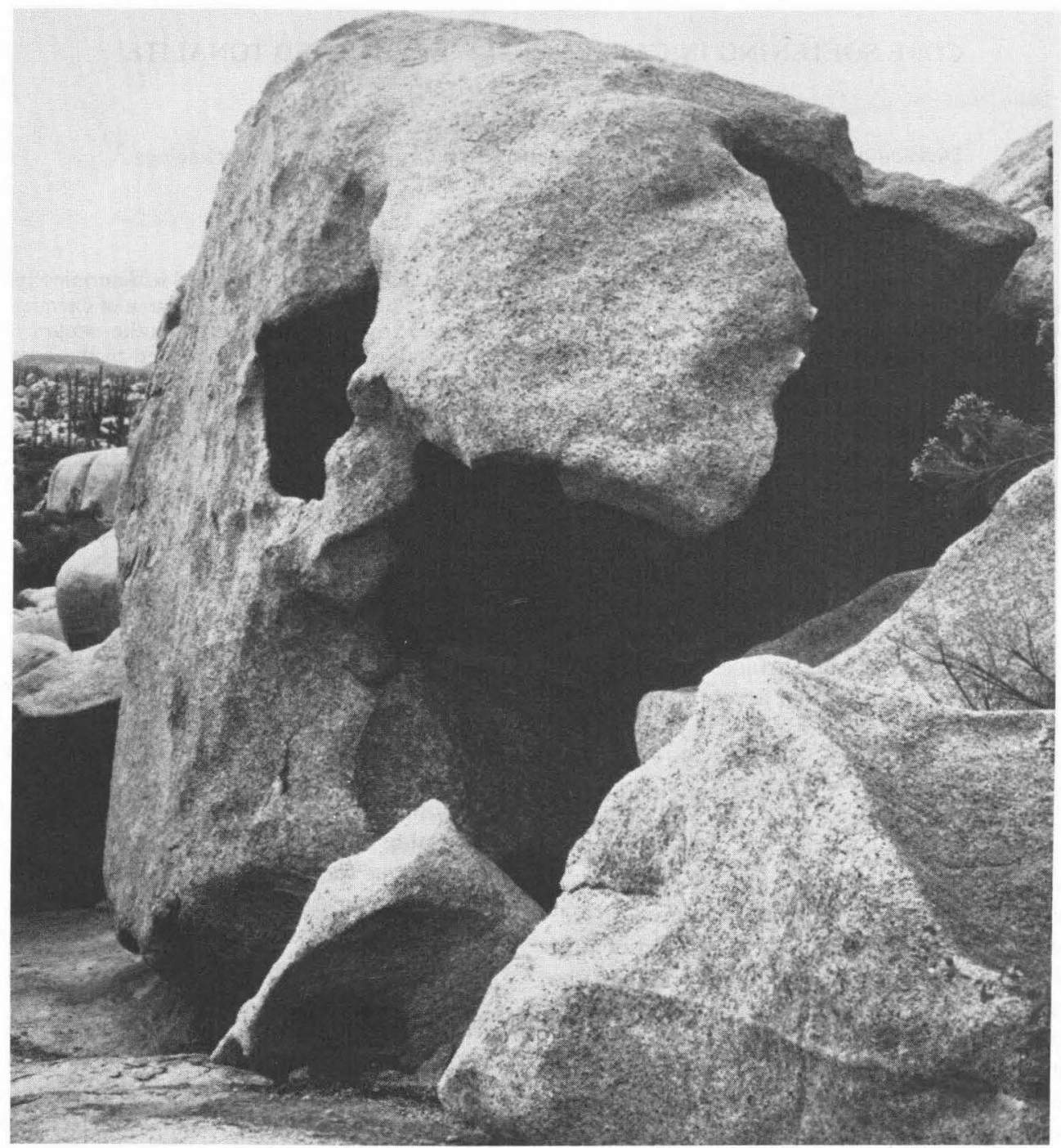

FIG. 1.-A representative core-softened tonalite boulder at Catavina, exhibiting cavernous weathering. The overhanging shell is $8 \mathrm{~cm}$ thick and the longest dimension of the cavernous hollow is just over $1 \mathrm{~m}$.

different rock exteriors relative to their interiors, allowing cavernous weathering to develop from differential hydration and salt weathering.

The present study was undertaken to investigate the weathering processes that have given rise to the products and morphology observed in the tonalite at Catavina, in particular those factors which have resulted in a differential hardness between the interior and exterior of the weathered rock.

\section{EXPERIMENTAL METHODS}

Homogenized powders were made from $\mathrm{kg}$-sized samples upon which whole rock chemistry was determined using X-ray fluorescence $\left(\mathrm{Al}_{2} \mathrm{O}_{3}, \mathrm{SiO}_{2}\right.$, total $\mathrm{Fe}$ as $\mathrm{FeO}$, $\mathrm{K}_{2} \mathrm{O}, \mathrm{TiO}_{2}$, and $\mathrm{MnO}$ ) and atomic absorption spectroscopy $\left(\mathrm{Na}_{2} \mathrm{O}\right.$ and $\left.\mathrm{MgO}\right)$. Specific mineral chemistries were obtained using an electron microprobe on polished mineral grain mounts. Ferrous iron was determined using a modified Wilson's method (Whipple 1974). 
Mineralogy was determined using X-ray diffraction on powders, thin section petrography, infrared spectroscopy on $\mathrm{KBr}$ pellets (Farmer 1974), and scanning electron microscopy on gold-coated rock fragments and individual mineral grains with an EDS unit. A DuPont moisture evolution analyzer was used for water analyses. Instruments developed for this study include an abrasion resistance hardness tester (ARHT), which measures the rock's surficial hardness, and a permeameter for measuring the water permeabilities of rock core samples.

\section{STUDY AREA}

The tonalite is part of a pluton in the Peninsular Ranges Batholith, located near Catavina at the northern end of the Jaraguay Block in central Baja California (fig. 2). The climate is arid with less than 5 inches of rainfall annually. The Cretaceous pluton exhibits cavernous weathering in much of its exposure and forms topographic lows, with surrounding mesas capped by Pliocene basalts. The present erosion surface of the pluton has formed below the level of the exhumed old erosion surface of the early Cenozoic mentioned in many geomorphic studies of Baja California (Gastil et al. 1975).

Within the study area the pluton is a medium-grained, light colored tonalite. Thin section point counts yield an average modal mineralogy of $65 \%$ plagioclase $\left(\mathrm{An}_{28}\right), 11 \%$ quartz, $5 \%$ potassium feldspar, $16 \%$ biotite, $3 \%$ hornblende, and trace amounts of zircon, titanite, and epidote. The quartz exhibits a small degree of myrmekitic texture with plagioclase. The plagioclase is microantiperthitic with areas as high as $70 \% \mathrm{~K}$-spar. In general all grains appear fresh and unaltered in the unweathered rocks, except that hornblende occasionally exhibits alteration to epidote. Variations in bulk composition and mineralogy within the pluton are significant within distances of hundreds of meters. Modal amounts of hornblende range from $5 \%$ to less than $1 \%$ by weight within the study area, and plagioclase compositions vary between $\mathrm{An}_{25}$ and $\mathrm{An}_{29}$. As will be discussed later, these intraplutonic variations are often greater than the chemical variations owing to weathering, necessitating the use of indicators other than changes in composition to trace the effects of weathering on these rocks.

The tonalite boulders sit in a soil of grus. Fresh outcrops are rare and restricted to areas recently exhumed by streams or road cuts. The surfaces of the weathered boulders are often coated with a weathering patina of various shades of brown. Individual cavernously weathered boulders are dominated by a single large cavern but may have several smaller holes in the overhanging shell or walls of the larger hollow. The interior walls of the cavernous hollow also have a weathering patina that may or may not be developed to the same extent as the respective exterior surface. Hard thin (1-2 cm) exfoliation shells occur on some of the weathered boulders and are found on surfaces which do not exhibit cavernous weathering. The exfoliation shells have a weathering patina on both their outside and inside surfaces.

No soluble salts or salt weathering effects were seen in the tonalite in the study area. Eolian erosion effects are also absent, although wind is an important agent for the removal of weathered debris. Insolation and frost action are expected to be insignificant in the study area, and no evidence for their action was observed at Catavina. Although biological activity will, in general, increase the chemical reactivity of surface and interstitial solutions (Antweiler and Drever 1983) and thus enhance weathering, there is little such biological action at Catavina, and certainly no relationship between biological activity and cavernous weathering.

Whole-rock chemical analyses of each rock zone of a representative, core-softened, cavernously weathered boulder (fig. 3) are shown in table 1: (A) friable rock interior, (B) rock exterior, and $(\mathrm{C})$ exfoliation shells. The exfoliation shells are the least weathered material obtainable from the outcrop, as determined from petrographic examination, amount of clay minerals formed, and the degree of hydration of the biotites. The exfoliation shells are also the most coherent material in the outcrop. Assuming that throughout the volume of the boulder the initial chemical and mineralogical variations of the parent material were small, then we can view the present compositions of the three zones as being the result of three different weathering histories 

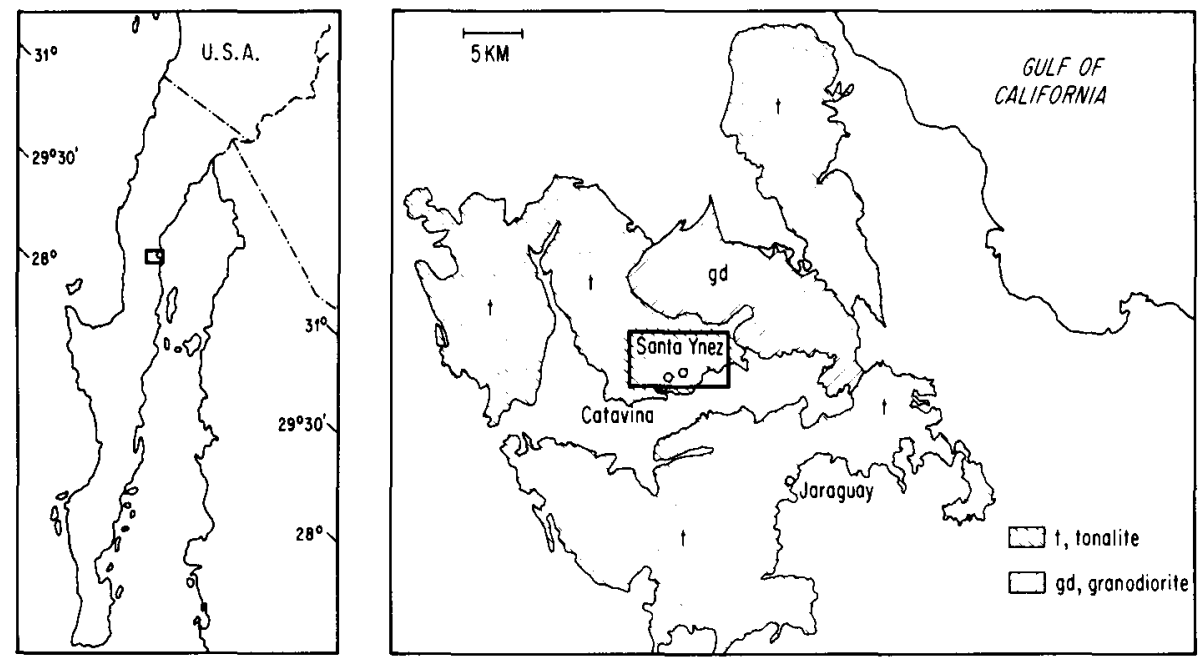

FIG. 2.-Index map of field area in Baja California (after Gastil et al. 1975).

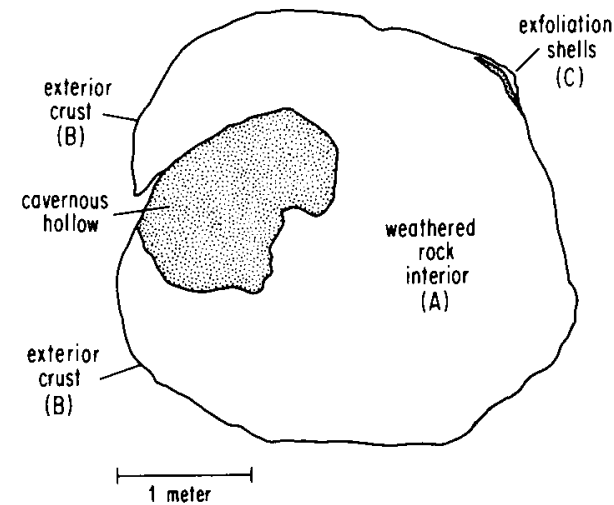

FIG. 3.-Schematic cross-section through a core-softened tonalite boulder exhibiting cavernous weathering. Analyses are given in table 1 for each weathering zone as well as for a sample from a nearby unweathered outcrop having slightly different mineralogy.

from a single parent material. Relatively fresh, unweathered rock (D) from a nearby outcrop recently exhumed by stream activity is included in table 1 for comparison with the weathered material. This sample (D) differs from the weathered samples $(\mathrm{A}-\mathrm{C})$ mineralogically by initially having more hornblende ( $4 \%$ as opposed to $1 \%$ ). For the three weathered zones of the boulder $(\mathrm{A}, \mathrm{B}, \mathrm{C}) \mathrm{TiO}_{2}$ has remained fairly constant with weathering. As would be expected with dissolution weathering, the ratio of $\mathrm{Al}_{2} \mathrm{O}_{3} / \mathrm{SiO}_{2}$ has increased with weathering, although only slightly. Both the exterior crust and the exfoliation shells have $\mathrm{Fe}^{3+} / \mathrm{Fe}^{2+}$ ratios greater than one, reflecting the precipitation of iron oxides near the rock surface, not greater oxidation of primary $\mathrm{Fe}^{2+}$ (see table 4). The weathered zones $\mathrm{A}$ and $\mathrm{B}$ have lost a considerable amount of $\mathrm{K}_{2} \mathrm{O}$ relative to the exfoliation shells and show a relative gain in $\mathrm{Na}_{2} \mathrm{O}$ and $\mathrm{CaO}$.

Comparing the results for this weathered boulder with the sample from the nearby unweathered outcrop (D), we see that the intraplutonic compositional variations are greater than those due to weathering, with perhaps the exception of $\mathrm{K}_{2} \mathrm{O}$. Thin section analyses of nearby boulders also indicate variations of several weight percent in modal amounts of the major minerals. In light of such variation it may be erroneous to assume that the parent whole rock composition was really constant over the small volume of the boulder. Therefore, changes in bulk composition between different areas are not solely due to weathering and may not be a good parameter with which to characterize the weathering processes that have given rise to the existing morphology. Indeed, the use of traditional ternary compositional diagrams such as kaolinization diagrams do not supply useful information in the present case, mainly because the bulk composition has undergone too little change as a result of weathering. It is necessary to look at changes in individual 
TABLE I

Whole Rock Chemistry

\begin{tabular}{|c|c|c|c|c|}
\hline Oxide & $\begin{array}{l}\text { Weathered } \\
\text { Interior }(A) \\
(\%)\end{array}$ & $\begin{array}{l}\text { Exterior } \\
\text { Crust (B) } \\
(\%)\end{array}$ & $\begin{array}{c}\text { Exfoliation } \\
\text { Shells (C) } \\
(\%)\end{array}$ & $\begin{array}{c}\text { Unweathered } \\
\text { Boulder (D) } \\
(\%)\end{array}$ \\
\hline $\mathrm{Al}_{2} \mathrm{O}_{3}$ & 15.5 & 15.2 & 15.4 & 15.6 \\
\hline $\mathrm{SiO}_{2}$ & 66.9 & 69.8 & 70.1 & 66.2 \\
\hline $\mathrm{Fe}_{2} \mathrm{O}_{3}$ & .98 & 1.48 & 1.00 & 1.13 \\
\hline $\mathrm{FeO}$ & 1.15 & .83 & .85 & 2.48 \\
\hline $\mathrm{MgO}$ & .85 & .91 & .71 & 1.99 \\
\hline $\mathrm{K}_{2} \mathrm{O}$ & 1.57 & 1.53 & 3.37 & 2.15 \\
\hline $\mathrm{Na}_{2} \mathrm{O}$ & 4.80 & 4.98 & 4.13 & 4.44 \\
\hline $\mathrm{CaO}$ & 2.76 & 2.92 & 2.47 & 4.04 \\
\hline $\mathrm{TiO}_{2}$ & .37 & .39 & .39 & .57 \\
\hline $\mathrm{MnO}$ & $<.1$ & $<.1$ & $<.1$ & $<.1$ \\
\hline $\mathrm{H}_{2} \mathrm{O}$ & .53 & .62 & .40 & .63 \\
\hline TOTAL & $95.5 \%^{\mathrm{a}}$ & $98.8 \%$ & $99.0 \%$ & $99.6 \%$ \\
\hline $\mathrm{Fe}^{3+} / \mathrm{Fe}^{2+}$ & .76 & 1.60 & 1.06 & .41 \\
\hline $\mathrm{Al}_{2} \mathrm{O}_{3} / \mathrm{SiO}_{2}$ & .23 & .22 & .22 & .24 \\
\hline
\end{tabular}

${ }^{a}$ Weathered samples give low totals for whole rock powder and individual mineral chemical analyses due to matrix effects brought about by weathering, affecting $\mathrm{SiO}_{2}$ and $\mathrm{Al}_{2} \mathrm{O}_{3}$ values while keeping $\mathrm{Al}_{2} \mathrm{O}_{3} / \mathrm{SiO}_{2}$ ratios fairly constant.

minerals and the growth of authigenic phases during weathering and how these affect the physical properties of the rock.

Differential weathering effects are extremely heterogeneous. Although the basic effects described above are seen in all coresoftened boulders at Catavina, the details will differ from boulder to boulder. The scenario presented in this paper focuses on a single cavernously weathered boulder, with supporting data from several others, and from surrounding material.

\section{FELDSPAR WEATHERING}

In hand specimen the feldspar grains of the weathered rock have a powdery material on their surfaces. In thin section the feldspars in the weathered interior (A) are permeated with orthogonal sets of microfractures. Under the SEM the fine powdery material on grain surfaces can be seen as authigenic silica and alumino-silica-bearing minerals on the basis of EDS analysis. Disaggregated samples were sonified and centrifuged to collect the $<10 \mu \mathrm{m}$ fraction. Infrared spectroscopy was used to identify the clay minerals. The spectra are dominated by kaolinite and quartz. IR spectra of whole rock powders were used to determine the wt $\%$ kaolinite in each of the rock zones of figure 3 . Table 2 gives the results. Comparing the kaolinite contents with the hardness data and general thin section and hand specimen observation, it is seen that the friability and weathered appearance of the rock zones are directly proportional to the kaolinite contents. Even the fresh rock (D) contains a small amount of kaolinite, indicating that some chemical weathering has occurred. The exfoliation shells have significantly lower kaolinite than the exterior surface which, in turn, has less than the friable interior. Thus kaolinite content can indicate the degree of chemical weathering that different areas of the rock have experienced.

Kaolinite and secondary quartz occur in mixed clusters on the surfaces of the primary mineral grains. This relationship is consistent with current hypotheses concerning the deposition of released alumina and silica as amorphous gels which subsequently crystal-

TABLE 2

KaOlinite Contents

\begin{tabular}{lc}
\hline $\begin{array}{l}\text { Sample areas } \\
\text { (see fig. 3) }\end{array}$ & $\begin{array}{c}\text { Kaolinite content } \\
\text { (wt \% whole rock) } \\
(\%)\end{array}$ \\
\hline Weathered interior (A) & 2.10 \\
Exterior crust (B) & 1.05 \\
Exfoliation shells (C) & .40 \\
Unweathered boulder (D) & .10 \\
\hline
\end{tabular}


lize to kaolinite and quartz (Yariv and Cross 1979; Loughnan 1969; Berner and Holdren 1979). Thin section analyses indicate that the interiors of the feldspar grains have been unaffected by kaolinization which has occurred along grain boundaries and fracture surfaces. Feldspar analyses (table 3) show that little change in overall feldspar composition has occurred with weathering. There appears to be a small relative loss of $\mathrm{Ca}$ and $\mathrm{Al}$ with a complimentary gain in $\mathrm{Na}$ and $\mathrm{Si}$. Since $\mathrm{Al}$ normally increases relative to $\mathrm{Si}$ during dissolution and weathering, these slight differences can best be explained as intraplutonic variations in the original composition.

Mixed layered illite/montmorillonite $(80 \%$ illite) was found in the surrounding soils but not in the weathering rock material. Most desert soils retain the alkalies and alkaline earths owing to incomplete leaching. This favors the formation of mixed layered clay minerals (Devore 1958). However, incomplete leaching of the soil does not necessarily reflect the situation of the weathering boulder resting on top of the ground surface. At Catavina, the boulders are effectively leached while the soil is not. Thus kaolinite is the initial weathering clay product of the rock. Only after granular disintegration occurs and the material enters the soil profile does mixed layered illite/montmorillinite begin to form in the study area.

TABLE 3

Plagioclase Chemistry

\begin{tabular}{lcc}
\hline Oxide & $\begin{array}{c}\text { Unweathered } \\
\text { rock } \\
(\%)\end{array}$ & $\begin{array}{c}\text { Weathered } \\
\text { rock } \\
(\%)\end{array}$ \\
\hline $\mathrm{Al}_{2} \mathrm{O}_{3}$ & 24.06 & 23.45 \\
$\mathrm{SiO}_{2}$ & 60.74 & 61.98 \\
$\mathrm{TiO}_{2}$ &. .9 & .01 \\
$\mathrm{Na}_{2} \mathrm{O}$ & 8.05 & 8.51 \\
$\mathrm{~K}_{2} \mathrm{O}$ & .27 & .31 \\
$\mathrm{CaO}$ & 5.97 & 5.28 \\
$\mathrm{FeO}$ & .08 & .08 \\
$\mathrm{BaO}$ & .04 & .02 \\
$\mathrm{TOTALS}^{\mathrm{b}}$ & $99.19 \%$ & $99.64 \%$ \\
$\mathrm{Al}_{2} \mathrm{O}_{3} / \mathrm{SiO}_{2}$ & $\mathrm{An}_{28.6}$ & $\mathrm{An}_{25.1}$ \\
\hline
\end{tabular}

${ }^{a}$ Below detection limits.

${ }^{b}$ As total iron.

\section{BIOTITE WEATHERING}

In all samples of the weathered tonalite at Catavina, the biotites are only slightly altered chemically and retain much of their luster. Xray diffraction patterns of the biotites from the rock zone of figure 3 show no vermiculite or other intermediate weathering products forming from the biotites. Chemical analyses for biotites from each zone (table 4) show that only minor changes in chemistry, such as an increase in the water content of the biotites, have occurred during weathering. Although total iron has changed only slightly, the $\mathrm{Fe}^{3+} /$ $\mathrm{Fe}^{2+}$ ratio has increased substantially in the weathered samples, to almost double the unweathered value in the weathered interior. Figures $4 A$ and $4 B$ show SEM micrographs of the (001) surface of an unweathered and a weathered biotite. The sheets of the weathered biotite are in the process of separation and breakup. The dissolution of the biotites is not homogeneous, as some layers weather differently and more rapidly than others. Figures $4 C$ and $4 D$ are micrographs of the (110) surface of a weathering biotite. There are two types of layers; more resistant, smooth layers alternate with less resistant, recessed layers. Energy dispersive X-ray analyses of these areas show that the recessed layers have higher $\mathrm{Fe}$ concentrations (up to about $40 \%$ ) than the more resistant layers. The (110) surfaces of these high-Fe layers appear highly etched and indicate that they are dissolving at a much faster rate than the low-Fe layers. Dissolution appears to be the major process of removal of the high-Fe material. The (110) surfaces of the low-Fe layers rarely have an etched appearance and more commonly show smooth fracture surfaces, as though physical transport of fragments were most important in removing this material from its present position. Wilson and Farmer (1970) found that Fe-rich lamellae in hornblende were completely altered and removed during weathering while the rest of the hornblende remained essentially unweathered. The greater susceptibility to dissolution of Fe-rich silicates results from the ability of $\mathrm{Fe}$ to change in oxidation state during weathering, rendering the structure unstable.

Biotite loses $\mathrm{Fe}$ by the following reactions (Farmer et al. 1971): 
TABLE 4

Biotite Chemistry

\begin{tabular}{|c|c|c|c|c|}
\hline Oxide & $\begin{array}{l}\text { Weathered } \\
\text { Interior (A) } \\
(\%)\end{array}$ & $\begin{array}{c}\text { Exterior } \\
\text { Crust (B) } \\
(\%)\end{array}$ & $\begin{array}{c}\text { Exfoliation } \\
\text { Shells (C) } \\
(\%)\end{array}$ & $\begin{array}{c}\text { Unweathered } \\
\text { Boulder (D) } \\
(\%)\end{array}$ \\
\hline $\mathrm{Al}_{2} \mathrm{O}_{3}$ & 14.57 & 15.45 & 14.00 & 14.58 \\
\hline $\mathrm{SiO}_{2}$ & 36.29 & 35.82 & 35.30 & 37.13 \\
\hline $\mathrm{TiO}_{2}$ & 3.66 & 3.84 & 3.48 & 2.97 \\
\hline $\mathrm{Na}_{2} \mathrm{O}$ & .09 & .58 & .02 & .06 \\
\hline $\mathrm{K}_{2} \mathrm{O}$ & 9.54 & 9.23 & 9.49 & 9.56 \\
\hline \multicolumn{5}{|l|}{$\mathrm{CaO}^{\mathrm{a}}$} \\
\hline $\mathrm{MgO}$ & 9.55 & 9.46 & 9.08 & 11.10 \\
\hline $\mathrm{FeO}$ & 12.20 & 11.64 & 14.57 & 14.58 \\
\hline $\mathrm{Fe}_{2} \mathrm{O}_{3}$ & 8.54 & 8.16 & 6.79 & 5.12 \\
\hline $\mathrm{MnO}$ & .41 & .36 & .44 & .28 \\
\hline F & .17 & .23 & .07 & .05 \\
\hline $\mathrm{Cl}$ & .03 & .04 & .02 & .03 \\
\hline $\mathrm{ZnO}$ & .03 & .20 & .05 & .10 \\
\hline $\mathrm{H}_{2} \mathrm{O}$ & 4.00 & 4.20 & 3.76 & 3.04 \\
\hline TOTALS & $99.08 \%$ & $99.21 \%$ & $97.07 \%$ & $98.61 \%$ \\
\hline $\mathrm{Fe}^{3+} / \mathrm{Fe}^{2+}$ & .63 & .49 & .42 & .32 \\
\hline
\end{tabular}

${ }^{\text {a } B e l o w ~ d e t e c t i o n ~ l i m i t s . ~}$

1) loss of hydroxyl protons (reversible)

$$
\begin{aligned}
& \mathrm{KFe}_{3}{ }^{2+}\left(\mathrm{Si}_{3} \mathrm{AlO}_{10}\right)(\mathrm{OH})_{2}+\frac{1}{2} \mathrm{O}_{2} \\
\rightarrow & \mathrm{KFe}^{2+} \mathrm{Fe}_{2}{ }^{3+} \mathrm{O}_{2}\left(\mathrm{Si}_{3} \mathrm{AlO}_{10}\right)+\mathrm{H}_{2} \mathrm{O}
\end{aligned}
$$

2) loss of octahedral iron (irreversible)

$$
\begin{gathered}
\mathrm{KFe}_{3}{ }^{2+}\left(\mathrm{Si}_{3} \mathrm{AlO}_{10}\right)(\mathrm{OH})_{2}+\frac{3}{4} \mathrm{O}_{2}+\frac{1}{2} \mathrm{H}_{2} \mathrm{O} \\
\rightarrow \mathrm{KFe}_{2}{ }^{3+}\left(\mathrm{Si}_{3} \mathrm{AlO}_{10}\right)(\mathrm{OH})_{2}+\mathrm{FeOOH}
\end{gathered}
$$

with the precipitation of amorphous or crystalline Fe-hydroxides. According to Fischer and Schwertmann (1975), hematite forms from the aggregation of the hydroxides and subsequent dehydration. Under conditions present at the rock surface in Catavina, i.e., periodic dessication under strong sunlight, low organic contents, and high Eh, dehydration to hematite is favored over the formation of goethite. Using scanning electron microscopy on the Catavina samples, these hematite aggregates are seen in association with the other secondary minerals in both the interior and exterior of the rock but occur in greater abundance towards the rock surface.

\section{OTHER WEATHERING PRODUCTS}

Trace amounts of authigenic calcite and gypsum have been found in weathered samples of the tonalite using scanning electron microscopy. The calcite occurs as irregular masses which have incorporated small grains of secondary kaolinite and quartz during growth. $\mathrm{CO}_{2}$ monometry indicates that calcite totals less than $0.001 \mathrm{wt} \%$ in the weathered rocks. Gypsum is even less abundant than calcite.

Based upon thin-section study, X-ray diffraction and scanning electron microscopy, hornblende remains essentially unweathered in these rocks. What small amount of iron is supplied by hornblende breakdown is far outweighed by iron supplied from biotite weathering.

\section{HARDNESS TESTING}

The hardness, as manifested in the abrasion resistance, of the different rock zones in figure 3 was measured using an abrasion resistance hardness tester (ARHT) developed for this purpose. A complete description of the instrument is found elsewhere (Conca and Cubba, in prep.). ARHT abrades the material by means of a diamond coring bit turning 

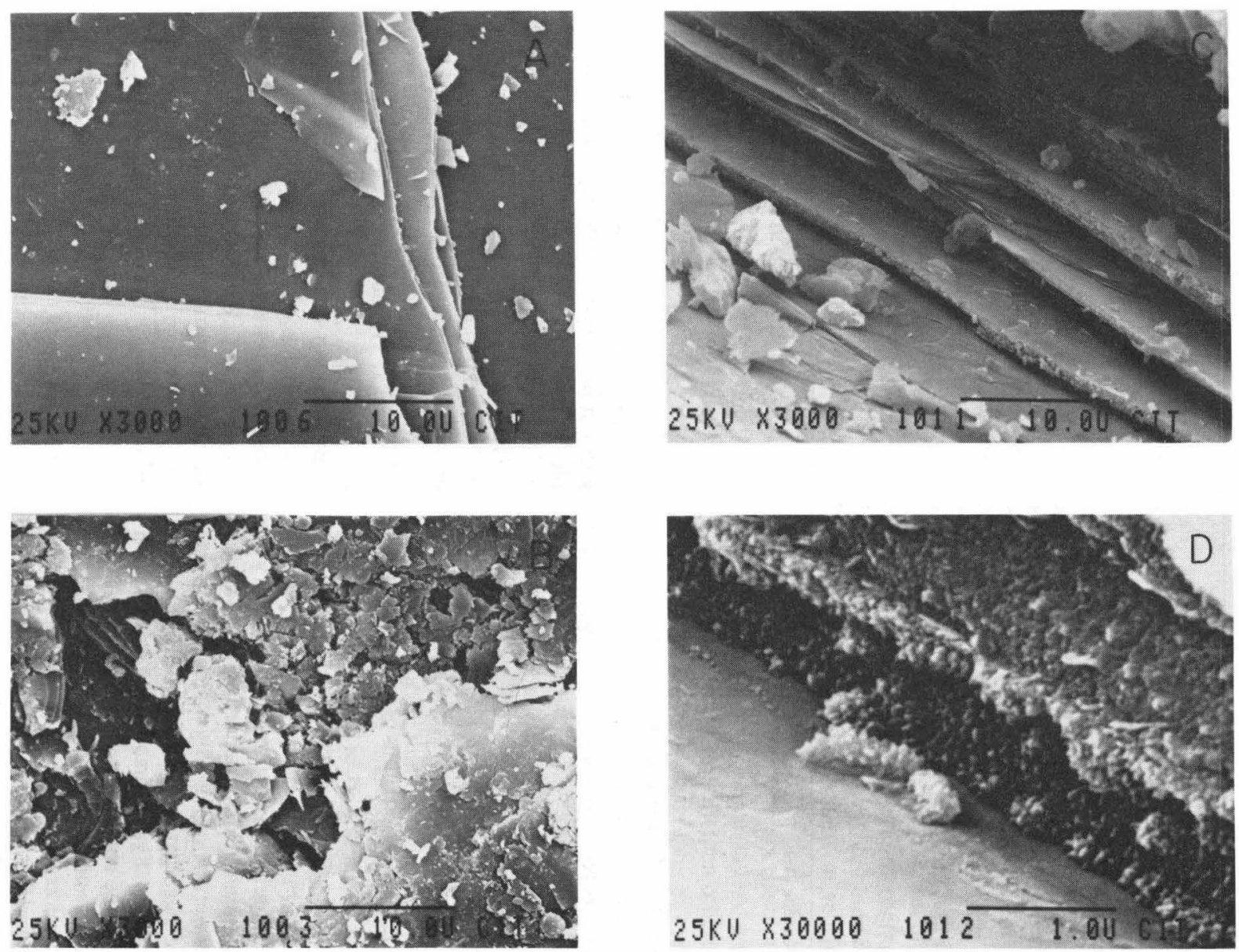

FIG. 4.-Electron micrographs of biotite surfaces. $(A)$ The (001) surface of an unweathered biotite. $(B)$ The $(001)$ surface of a weathered biotite. $(C)$ Oblique view of the (110) surface of a biotite from a weathered boulder interior showing the alternating low and high-Fe layers (resistant and recessed layers, respectively). (D) Higher magnification view of (C) showing the etched (110) surface of a high-Fe layer. Scale bar is $10 \mu \mathrm{m}$ in (A), (B), and (C), and $1 \mu \mathrm{m}$ in (D). 
slowly using a constant-torque motor under constant normal force. The measured time required to abrade to a fixed depth is related to the abrasion resistance of the material. The hardness value of a material $\left(\mathrm{H}_{\mathrm{a}}\right)$ and the coefficient of relative hardening for an exterior surface $(C)$ are defined here as:

$$
\begin{aligned}
\mathrm{H}_{\mathrm{a}} & =\frac{\mathrm{F} \cdot \mathrm{t}}{\mathrm{D}} \times 10^{-5} \\
\mathrm{C} & =\frac{\mathrm{H}_{\mathrm{a}} \text { (exterior) }}{\mathrm{H}_{\mathrm{a}} \text { (interior) }}
\end{aligned}
$$

where $\mathrm{H}_{\mathrm{a}}$ is the abrasion resistance hardness value, $\mathrm{C}$ is the coefficient of relative hardening, $F$ is the normal force (Newtons), $D$ is the depth of penetration (meters), and $t$ is the time (seconds).

For most rock materials $\mathrm{H}_{\mathrm{a}}$ is found to range from approximately 1 to 100 , e.g., about 10 for a well-cemented sandstone and about 50 for an unweathered granitic rock. Values of $C$ greater than 1 indicate case hardening or core softening. At Catavina, $\mathrm{C}$ is $2.26 \pm 0.3$, indicating a moderate degree of relative hardening. The relationship between $\mathrm{H}_{\mathrm{a}}$ and kaolinite content is shown in figure 5 . Abrasion resistance hardness values vary inversely with kaolinite contents, suggesting that kaolinite formation is related to changes in the rock's physical properties. Small variations in the amount of kaolinite produce large differences in the hardness.

\section{DISCUSSION}

Although hematite occurs in exterior coatings at Catavina, its presence is not a contributor to the differential hardness between the exterior and the interior. Exteriors often have no coatings while the friable interior walls of cavernous hollows sometimes have considerable accumulations of hematite. The presence of such accumulations on the friable interior walls has decreased their friability relative to similar interior walls not having such accumulations (i.e., they do have a minor local case-hardening effect). However, the presence of a case-hardening cement is of secondary importance compared to kaolinization and the degree of chemical weathering undergone by different areas. The friable rock interior has undergone considerably more chemical weathering and has had more

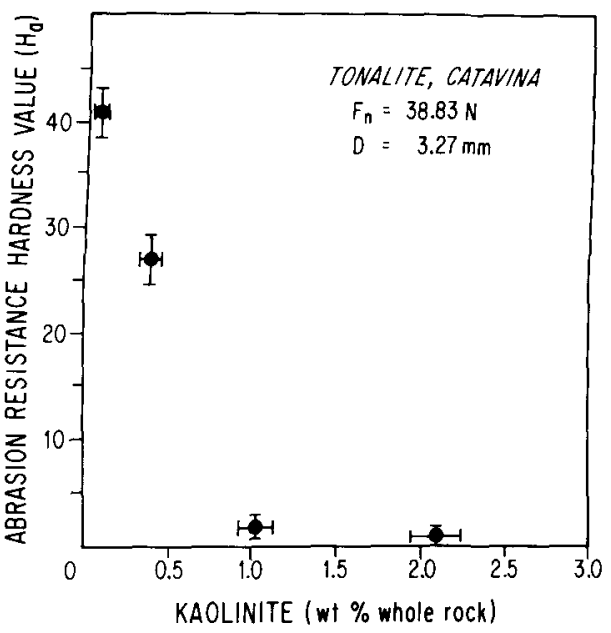

FIG. 5.-A plot of the abrasion resistance hardness values $\left(\mathrm{H}_{\mathrm{a}}\right)$ against the kaolinite contents of the different rock zones of figure 3 .

kaolinite formed than the exterior. The hard exfoliation shells contain even less kaolinite. The dissolution of feldspar and quartz surfaces and the formation of kaolinite have had the most profound effects on the rock's physical properties.

Therefore, the tonalite at Catavina has actually become core-softened as a result of differential weathering rates between the rock interior and exterior. This is different from the classical examples of case hardening in which the exterior becomes harder and more resistant to weathering than the original rock prior to weathering, usually as the result of precipitation of a secondary phase at the rock surface (Anderson 1931; Conca and Rossman 1982).

The above observations suggest that weathering at Catavina occurs by disruption of the granular framework. This framework can be categorized as mechanical, such as the close-packed geometric arrangement of grains like a 3-dimensional jigsaw puzzle, and as chemical, such as bonds between grain surfaces and bonds within the lattice of the minerals themselves. The framework can be disrupted in many ways and will affect the coherence of the material. Disruption of the geometric framework begins immediately after the rock has moved from its initial P-T conditions. This results from the heterogeneous response of the different minerals to 
changes in temperature and pressure and is usually manifested as microfractures. Subsequently, removal of material in solution along these fractures, hydration of primary phases and crystallization of secondary minerals will further disrupt the geometric framework. Bonds between and within grains will also be disrupted by the same processes, the most important being hydration of intergranular surface bonds. In the interior of the Catavina tonalites the rock is disintegrating both along primary grain boundaries and along cleavage planes within the feldspars and biotites.

\section{WATER PERMEABILITY AND INFILTRATION INTO CORE-SOFTENED BOULDERS}

Core-softening depends upon the relative degree of chemical weathering between different areas of the rock, which in turn depends upon the changes in moisture content of those areas. The effect that core softening has on the water content and flux within a boulder, and what this means for the continued development of the cavern, will be modeled under the simplest conditions of one-dimensional flow, where the gravitational head is much smaller than the matric suction (a condition satisfied for infiltration over the small volume of an initially dry boulder).

Infiltration of water into a non-saturated boulder and its subsequent redistribution is described by unsaturated flow, in which Darcy's law takes the form;

$$
\mathbf{q}=-\mathbf{K}(\psi) \nabla \mathbf{H}
$$

where $q$ is the flux density (i.e., the volume of water flowing through a unit cross-sectional area per unit time). $\nabla \mathrm{H}$ is the hydraulic gradient (supplied by either a pressure head, gravitational head, or matric suction head) and $\mathrm{K}$ is the hydraulic conductivity (or water permeability), which is a function of the matric suction, $\psi$. Matric suction is the negative pressure or suction generated by both capillary and water film effects (Swartzendruber 1969). The hydraulic conductivity, K, is a product of the intrinsic permeability of the material and the fluidity of the water.

The flow equation in one-dimension describing the change in volumetric water content, $\theta$, with time, $t$, can be obtained by dif- ferentiating Darcy's law with respect to distance from the surface, $x$ :

$$
\frac{\partial \theta}{\partial t}=-\frac{\partial q}{\partial x}
$$

For an unsaturated system where the hydraulic gradient is dominated by matric suction (as in the present case), the flow equation becomes:

$$
\frac{\partial \theta}{\partial \mathrm{t}}=\frac{\partial}{\partial \mathrm{x}}\left[\mathbf{K}(\psi) \frac{\partial \psi}{\partial \mathrm{x}}\right]
$$

If $\mathrm{K}$ remains fairly constant, then equation (2) reduces to:

$$
\frac{\partial \theta}{\partial t}=K \frac{\partial^{2} \psi}{\partial x^{2}}
$$

Green and Ampt (1911) developed a simplified approach to the solution of equation (3). Their principle assumptions are that the wetting front is distinct and sharp and that the matric suction at this wetting front is effectively constant. This approach gives the infiltration rate, $i$, and the maximum depth of infiltration, $L_{f}$, as (Hillel 1971):

$$
\begin{gathered}
i=\Delta \theta\left(\frac{K}{2 \mathrm{t}} \frac{\Delta \mathrm{H}}{\Delta \theta}\right)^{1 / 2} \\
\mathrm{~L}_{\mathrm{f}}=\left(2 \mathrm{tK} \frac{\Delta \mathrm{H}}{\Delta \theta}\right)^{1 / 2}
\end{gathered}
$$

where $\Delta \theta$ is the difference between the initial and final water contents of the rock $(\Delta \theta$ equals the porosity for an initially dry boulder that becomes saturated upon infiltration), and $\Delta H$ is the change in hydraulic pressure or matric suction from the point of infiltration to the wetting front.

Figure 6 is a cross-section of an idealized core-softened boulder which will provide the parameters for the following model calculations. It is based upon observations from several field areas including Catavina. The boulder, $3 \mathrm{~m}$ in diameter, has a single cavern $1 \mathrm{~m}$ in diameter and an exterior less-weathered zone $10 \mathrm{~cm}$ thick. The interior of the boulder is uniformly weathered. Material immediately behind the cavern interior wall to a depth of $1 \mathrm{~cm}$ is the most highly weathered material in the rock and constitutes a third 


\section{Infiltration into an Idealized Core-softened Boulder}

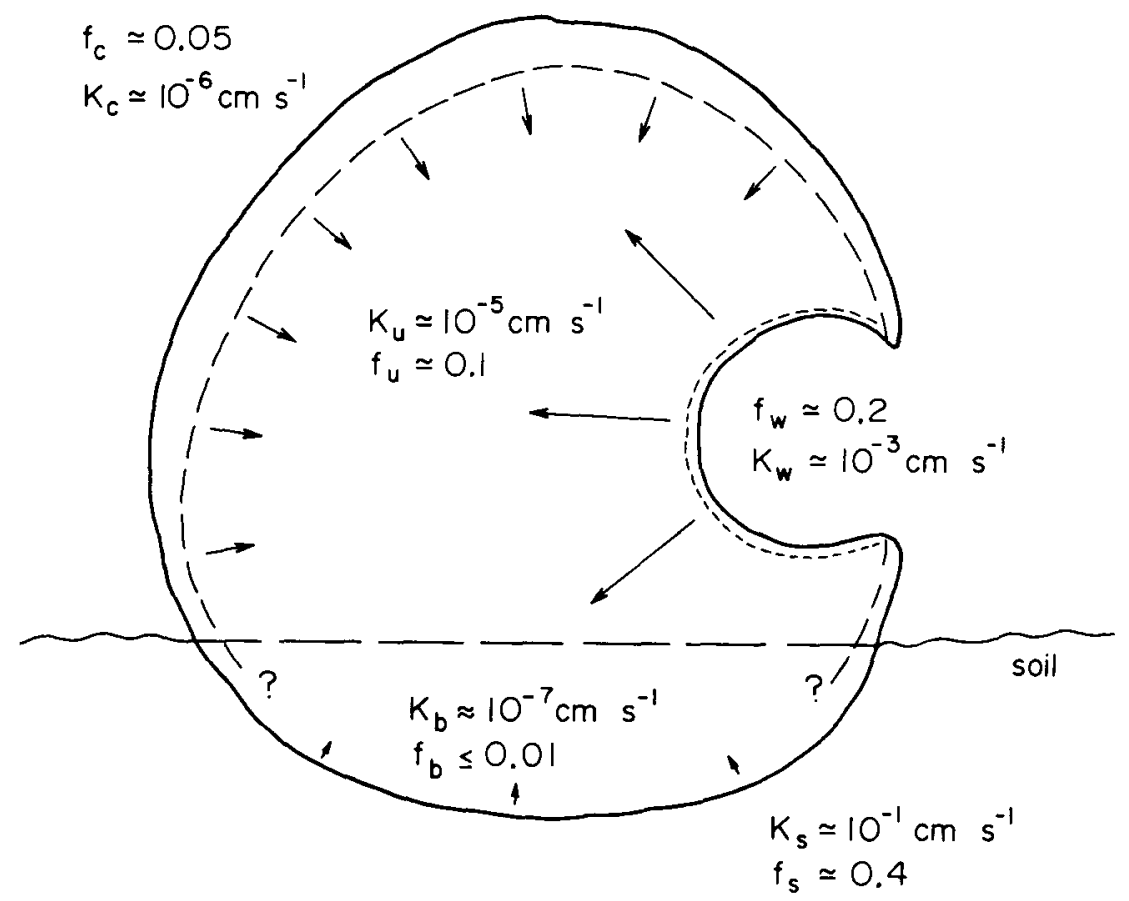

FIG. 6.-Cross-section through an idealized core-softened boulder undergoing infiltration by rainwater. Hydraulic conductivities, $K$, are shown for the different zones of the boulder, exterior $\left(K_{c}\right)$, interior $\left(K_{u}\right)$, cavern interior wall $\left(K_{w}\right)$ and basal zone $\left(K_{b}\right)$, and for the soil $\left(K_{s}\right)$. Porosity values (f) are given for the same zones. Boundaries between different zones are indicated by dotted lines. Direction of water flow in the boulder is approximated by arrows.

zone. Included in this idealization is a basal zone near or at the soil horizon. Many boulders in the field exhibit a basal zone which is much less weathered than any of the above zones. The boulder is embedded in the surrounding soil to a depth of $1 \mathrm{~m}$. These conditions, while by no means universal, are approximated in many field areas.

Hydraulic conductivities of different zones for core-softened boulders were measured under saturated conditions using a permeameter designed for rock material (methods for permeameters are reviewed by Klute 1965). Hydraulic conductivities for differentially weathered rock varied considerably, from less than $10^{-9} \mathrm{~cm} / \mathrm{sec}$ to as high as $10^{-3} \mathrm{~cm} /$ sec (approximately $10^{-6}$ darcy to over 1 darcy). In general, interior values were at least an order of magnitude above exterior values, with highly weathered zones several orders of magnitude above the conductivities of the exterior. In figure 6, the different zones of rock are assigned values of hydraulic conductivity, $\mathrm{K}$, and porosity, $\mathrm{f}$, based on relationships observed in the field.

In the present case of the weathering tonalite, differences in permeability between different zones of the boulder result more from changes in the number and extent of interconnecting passageways than from changes in their fundamental properties (Norton and Knapp 1977). Thus, the matric suction will remain fairly constant between different zones in the dry state and will be assigned a value of $10^{3} \mathrm{~cm}$, a reasonable estimate based on the fine nature of the pore structure (Lambe and Whitman 1969).

Infiltration of water into the boulder will be modeled for steady state infiltration from all surfaces, i.e., water is supplied to the surface by rain at a rate greater than infiltration, as will happen for the duration of a major storm. 
TABLE 5

Saturation Times

Time required to saturate particular zone Zone

(see fig. 6)

Time

(sec)

cavern interior wall

exterior

basal zone

.1

$2.5 \times 10^{3}$

$5.0 \times 10^{5}$

Time required to saturate entire boulder by infiltration through particular zone
Zone

(see fig. 6)

cavern interior wall

exterior

basal zone
Time

(sec)
Overall infiltration can be divided into three parts: infiltration through the cavern interior wall, through the exterior zone, and through the basal zone. Equation (5) can be used to determine the time required to saturate each zone after the onset of the storm. These saturation times are given in table 5 . It can be seen from table 5 that infiltration from the cavern wall into the boulder interior begins almost immediately, and that the time required to saturate the entire boulder by infiltration through the cavern will be:

$$
\begin{gathered}
\mathrm{t}=\frac{0.1(300 \mathrm{~cm})^{2}}{2\left(10^{-5} \mathrm{~cm} / \mathrm{sec}\right)\left(10^{3} \mathrm{~cm}\right)}=4.5 \\
\times 10^{5} \mathrm{sec}
\end{gathered}
$$

or just over 5 days. Compared to this, saturation of the boulder by infiltration through the exterior will take considerably longer, over 50 days.

After infiltration stops, either when the boulder is saturated or the storm ends, the rock will begin to dry out. The drying process occurs in two stages (Hillel 1971): (1) an early, constant-rate stage, during which the evaporation rate is determined by the external and surface conditions, and (2) a fallingrate stage, during which the evaporation rate from the rock is lower and is determined by the material's conductivity.

The flow equation for drying will be similar to equation (2) (Gardner and Hillel 1962). However, the solution cannot be approxi- mated by Green and Ampt's approach because the assumptions used for a discreet wetting front do not hold for this situation. It is assumed, therefore, that the evaporation rate is low enough so that all depths are losing water at the same rate per unit volume, making water loss independent of depth. For mathematical convenience, let $\mathrm{x}$ be the distance to the rock surface from the opposite end of the drying profile. If $E$ is the rate of water loss per unit volume per unit time, then:

$$
\frac{\partial \theta}{\partial \mathrm{t}}=\mathrm{K} \frac{\partial^{2} \psi}{\partial \mathrm{x}^{2}}=-\mathrm{E}
$$

for constant conductivity. Integrating gives:

$$
-E x=K \frac{d \psi}{d x}+\text { constant }
$$

the constant of integration being zero for no flow across the boundary $\mathrm{x}=0$, i.e., no water flow into the opposite side of the boulder. For a given suction gradient the total water loss will vary with the hydraulic conductivity, K. Therefore, even though no rate calculations can be made without information on the suction gradient during dessication for the boulder in figure 6 , there will be an order of magnitude more flow through the cavern interior wall than through the exterior regardless of the suction gradient.

During the initial stage, water moves outward in response to the evaporation-induced suction gradient at the surface. The rate can remain fairly constant as the increasing suction gradient due to decreased water content tends to compensate for the decreasing hydraulic conductivity (Hillel 1971). Eventually, the water content, $\theta$, becomes so low that no more water is supplied to the surface, the suction gradient is at a maximum, and the surface becomes air-dry. The second stage begins, and is accompanied by an inwardmoving drying front. Movement of water from this front to the surface occurs by vapor diffusion. After the surface is brought to dryness Gardner (1959) determined that the evaporative flux, $q_{e}$, takes a similar form to equation (4):

$$
\mathrm{q}_{\mathrm{e}}=\Delta \theta\left(\frac{\mathrm{D}}{\pi \mathrm{t}}\right)^{1 / 2}
$$


where $\mathrm{D}$ is the diffusivity of the material. Normally D is related to the hydraulic conductivity, K, by the following (Hillel 1971):

$$
D(\theta)=K(\theta) \frac{d \psi}{d \theta}
$$

both being functions of the water content. For a given matric suction, $\psi$, and water content, $\theta$, the evaporative flux will vary with $\mathrm{K}^{1 / 2}$ indicating that during the second stage of drying the moisture flux through the cavern wall will again be greater than through the exterior.

Thus the main effect that core-softening has on the moisture regime of the boulder is the change in the hydraulic conductivities of the different zones and the resultant change in the water flux, q. The lower conductivity of the exterior will reduce the flow of the underlying material during both infiltration and dessication (the effect will be the same for a case-hardened material). Since the amount and chemical reactivity of the interstitial water will determine the amount of chemical weathering that occurs, then, for similarly reactive waters over the volume of the boulder, the material behind the cavern interior wall will show the greatest weathering effects due to the highest fluxes.

\section{ORIGIN OF CORE SOFTENING}

The above model calculations indicate that core softening is a stable, self-reinforcing process that should continue to operate until either the boulder is totally hollow or the system is externally perturbed. Once the cavern is initiated, by whatever mechanism, it will begin to effect the flux of water, both during infiltration and dessication. During early stages of cavern development, these effects will be only local, but they will increase with time as the cavern enlarges and more moisture is diverted through the cavern wall. As the cavern develops, a zone with the highest degree of weathering should precede it into the boulder.

The exact causes of core-softening and cavern initiation remain problematical but, most likely, result from the combined action of a variety of mechanisms. Spatial differences in the initial properties of the material, such as structural variations (jointing, sedimentary structures), compositional or petrological variations, grain-size differences, etc., can result in differential weathering effects. Temporal variations in the properties of different areas of the rock such as devitrification of volcanic glass along joint planes (Conca in preparation), secondary cementation (by calcite, silica, iron oxides, etc.) and permeability changes can have great differential effects, as can spatial variations in external conditions such as microclimate and ground water flow.

At Catavina, the development of coresoftening and cavernous weathering is a function of differences in the moisture flux and reactivity. It has been observed by the authors that the levels of the basal zones of differentially weathered rocks are related to the soil horizon (either present or past horizons) and basal zones often form the floors of the caverns. Many caverns appear to be initiated at the soil surface-rock interface. Dragovich (1969) discusses the importance of the soil surface-rock interface in terms of a more rapid weathering rate due to increased moisture content and thermal effects through temperature cycling. The water existing in the upper soil horizon will have higher chemical reactivities due to increased dissolved $\mathrm{CO}_{2}$ and organic acids (Antweiler and Drever 1983; D. Melchior personal comm.). Also, the wetness gradient, $\partial \theta / \partial \mathrm{x}$, across the rocksoil interface will be smaller than the gradient across the rock-atmosphere interface during drying because of the higher soil humidity relative to the atmosphere, thus lowering the water flux through the base during dessication, an effect which will be important mainly in arid environments.

There is an important size-dependence of core-softening implied by equation (5). The larger the boulder, the longer it will take for infiltration into the interior, such that a size range will be reached for a particular situation where the boulder cannot become coresoftened as a whole, although locally differential effects will develop. Similarly, the smaller the boulder the less important will be differences in infiltration rates, and the rock will weather more evenly.

CONCLUSION

The weathering effects on the tonalite can be summarized as follows:

1) Kaolinite, quartz, and hematite are the major weathering products formed. Calcite and gypsum have formed in trace amounts. 
2) Biotite has undergone loss of $\mathrm{Fe}^{2+}$ without major breakdown in structure and without the formation of a measurable amount of phases such as vermiculite or chloritesaponite. Weathering has increased the water content of the biotite.

3) Feldspar has weathered along cleavage surfaces and grain boundaries to supply $\mathrm{Al}$ and (along with minor dissolution of quartz) Si for the formation of kaolinite and secondary quartz. Mixed layer illite/montmorillinite clays were not found in the weathered samples, but were found in the surrounding soils.

4) Less kaolinite is present in the exterior than in the more friable interior, and the feldspars are not as highly fractured in the exterior as they are in the interior.

5) Most of the hematite occurs towards the rock surfaces.

6) The degree of relative hardening of the exterior $(C)$ was equal to $2.26 \pm 0.3$. Abrasion resistance hardness values $\left(\mathrm{H}_{\mathrm{a}}\right)$ inversely correlate with kaolinite contents.

The above observations indicate that tonalite boulders at Catavina are core-softened as a result of greater kaolinization of the interior.

Model calculations for one-dimensional flow within a boulder indicate that coresoftening influences the flow of water by changing the hydraulic conductivities (water permeabilities) of different areas, thus increasing the flux of water through the cavern interior wall relative to the exterior.

ACKNOWLEDGMEnTs.-We would like to thank Rosemarie Cubba and Peter Larson for assisting us in the field, and Robert P. Sharp and Ronald F. Scott for insightful comments and discussion. This research was supported in part by grants from Sigma Xi and the National Science Foundation (EAR 82-12590).

\section{REFERENCES CITED}

Anderson, A. L., 1931, Geology and mineral resources of eastern Cassia County: Idaho Bureau Mines Geol. Bull. 14, p. 56-61.

Antweiler, R. C., and Drever, J. 1., 1983, The weathering of a late Tertiary volcanic ash: importance of organic solutes: Geochim. Cosmochim. Acta, v. 47, p. 623-629.

Berner, R. A., and Holdren, G. R., JR., 1979 , Mechanism of feldspar weathering-II. Observations of feldspars from soils: Geochim. Cosmochim. Acta, v. 43, p. 1173-1186.

ConcA, J. L., 1984, Field and laboratory studies of geologic case hardening: Ant, Jour. U.S. in press.

— of sandstone: Geology, v. 10, p. 520-523.

DeVore, G. W., 1958, The surface chemistry of feldspars as an influence on their decomposition products: Proc. Nat. Conf. Clays and Clay Minerals, v. 6, p. 26-41.

Dragovich, D. J., 1969, The origin of cavernous surfaces (tafoni) in granitic rocks of southern South Australia: Z. Geomorph., v. 13, p. 163181.

Evans, I. S., 1970, Salt crystallization and rock weathering: a review: Revue Geomorph. Dynam., v. 19, no. 4, p. 153-177.

FAHEY, B. D., 1973, An analysis of diurnal freezethaw and frost heave cycles in the Indian Peaks Region of the Colorado Front Range: Arctic Alpine Res., v. 5, p. 269-281.

FARMER, V. C., 1974, The infrared spectra of minerals: Mineral. Soc. Mon. 4, 539 p.

; Russel, J. D.; McHardy, W. J.; Newman,

A. C. D.; Alrichs, J. L.; and Rimsaite, J. Y. H., 1971. Evidence for loss of octahedral iron from oxidized biotites and vermiculites: Mineral. Mag., v. 38, p. 121-137.

Fischer, W. R., and SchwertmanN, U., 1975, The formation of hematite from amorphous iron(III)hydroxide: Clays and Clay Minerals, v. 23, p. 33-37.

Gardner, W. R., 1959, Solutions of the flow equation for the drying of soils and other porous media: Soil Sci. Soc. Amer. Proc., v. 23, p. 183-187.

—._, and Hillel, D. I., 1962, The relation of external evaporative conditions to the drying of soils: Jour. Geophys. Res., v. 67, p. 4319-4325.

Gastil, R. G.; Phillips, R. P.; and Allison, E. C., 1975, Reconnaissance geology of the state of Baja California: Geol. Soc. America Mem. 140, $170 \mathrm{p}$.

Goudie, A., 1974, Further experimental investigations of rock weathering by salt and other mechanical processes: Z. Geomorph. N. F. Suppl. Bd., v. 21, p. 1-12.

Green, W. H., and Ampt, G. A., 1911, Studies on soil physics: I. Flow of air and water through soils: Jour. Agr. Sci,, v. 4, p. 1-24.

Hrleel, D., 1971, Soil and Water Physical Principles and Properties: New York, Academic Press, $288 \mathrm{p}$.

Jennings, J. N., 1968, Tafoni, in Falrbridge, R. W., ed., The Encyclopedia of Geomorphology, Vol. III: New York: Reinhold Book Corp., p. 1103-1104.

KLUTE, A., 1965, Laboratory measurements of hydraulic conductivity of saturated soil: methods of soil analysis: Am. Soc. Agron. Mon. 9, p. $210-221$.

Lambe, T. W., and Whitman, R. V., 1969, Soil Mechanics: New York, Wiley, 553 p. 
Loughnan, F. C., 1969, Chemical Weathering of the Silicate Minerals: New York, American Elsevier Publishing Co., 154 p.

Mustoe, G. E., 1982, The origin of honeycomb weathering: Geol. Soc. America Bull., v. 93, p. $108-115$.

Norton, D., and Knapr, R., 1977, Transport phenomena in hydrothermal systems: the nature of porosity: Am. Jour. Sci., v. 277, p. 913-936.

RiCE, A., 1976, Insolation warmed over: Geology, V. 4, p. 61-62.

Selby, M. J., 1971, Salt weathering of landforms and an Antarctic example, in Proc. Sixth Geog. Conf.: Christchurch, New Zealand Geog. Soc., p. $30-35$.

SWARTZENDRUBER, D., 1969, The flow of water in unsaturated soils, in DEWIEST, R. J. M., ed.,
Flow through Porous Media: New York, Academic Press, p. 215-287.

Whalley, W. W. B., and McGreevy, J. P., 1983, Weathering: Prog. Phys. Geog., v. 7, p. 559-586.

Whipple, E. R., 1974, A study of Wilson's determination of ferrous iron in silicates: Chem. Geology, v. 14, p. 223-238.

White, S. E., 1976, Is frost action really only hydration shattering? A review: Arctic Alpine Res., v. 8, p. 1-6.

WiLSON, M. J., and FARMer, V. C., 1970, Study of weathering in a soil derived from a biotitehornblende rock: Clay Min., v. 8, p. 435444.

YarIV, S., and Cross, H., 1979, Geochemistry of Colloid Systems: New York, Springer-Verlag, $450 \mathrm{p}$. 